University of Wollongong

Research Online

Faculty of Engineering and Information

Faculty of Engineering and Information

Sciences - Papers: Part A

Sciences

$1-1-2014$

\title{
Goaf frictional ignition and its control measures in underground coal mines
}

Gaofeng Wang

University of Wollongong, gw508@uowmail.edu.au

Ting Ren

University of Wollongong, tren@uow.edu.au

Christopher David Cook

University of Wollongong, chris_cook@uow.edu.au

Follow this and additional works at: https://ro.uow.edu.au/eispapers

Part of the Engineering Commons, and the Science and Technology Studies Commons

Research Online is the open access institutional repository for the University of Wollongong. For further information contact the UOW Library: research-pubs@uow.edu.au 


\title{
Goaf frictional ignition and its control measures in underground coal mines
}

\author{
Abstract \\ Goaf Frictional Ignition (GFI) poses a serious threat to the safety of underground coal mines, and has \\ caused many underground fires and catastrophic explosions. This paper examined occurrences of GFI \\ incidents and the underlying mechanisms of ignition source and environment. Most of these incidents \\ were attributed to rock on rock frictional ignition. The eventuation of frictional ignition relies on the \\ presence of hot spots with enough incendive ignition energy, which requires a minimum threshold sliding \\ distance and sliding velocity. The incendivity of the environment can be enhanced by the presence of \\ liquid carbon hydrogen, the increase of virgin rock temperature, and the presence of hydrocarbon gases \\ from thermal decomposition product of coal volatile. The paper discussed the newly proposed concerns \\ on the varying incendivity of environment; finally it summarized the GFI engineering controls and \\ discussed their applicability.

\section{Keywords} \\ underground, goaf, coal, frictional, mines, ignition, its, control, measures \\ Disciplines \\ Engineering | Science and Technology Studies

\section{Publication Details} \\ Wang, G. F., Ren, T. X. \& Cook, C. (2014). Goaf frictional ignition and its control measures in underground \\ coal mines. In X. He, H. Mitri, B. Nie, Y. Wang, T. X. Ren, W. Chen \& X. Li (Eds.), Progress in Mine Safety \\ Science and Engineering II: Proceedings of the 2nd International Symposium of Mine Safety Science and \\ Engineering (pp. 451-459). United Kingdom: Taylor \& Francis Group.
}




\title{
Goaf frictional ignition and its control measures in underground coal mines
}

\author{
G.F. Wang, T. X. Ren \& C. Cook \\ Faculty of Engineering and Information Sciences, University of Wollongong, New South Wales 2522, Australia
}

ABSTRACT: Goaf frictional ignition (GFI) poses a serious threat to the safety of underground coal mines, and has caused many underground fires and catastrophic explosions. This paper examined occurrences of GFI incidents and the underlying mechanisms of ignition source and environment. Most of these incidents were attributed to rock on rock frictional ignition. The eventuation of frictional ignition relies on the presence of hot spots with enough incendive ignition energy, which requires a minimum threshold sliding distance and sliding velocity. The incendivity of the environment can be enhanced by the presence of liquid carbon hydrogen, the increase of virgin rock temperature, and the presence of hydrocarbon gases from thermal decomposition product of coal volatile. The paper discussed the newly proposed concerns on the varying incendivity of environment; finally it summarized the GFI engineering controls and discussed their applicability.

\section{INTRODUCTION}

Goaf frictional ignition (GFI) refers to the ignition of flammable gas mixture by friction in the goaf area. It poses great threats to the underground coal mine safety. Goaf fires and explosions emanating from it have caused substantial property losses and casualties all around the world. On July 16th, 1986, 12 people were killed by an explosion in Moura No. 4 Underground Mine in Central Queensland, and GFI was suspected as one of the two possible ignition sources (Lynn et al. 1986). In USA 1997, an explosion occurred in Upper Big Branch underground coal mine and caused considerable property loss, which was surely induced by GFI (Page et al. 2010). A fatal explosion happened in Sago Mine, West Virginia, USA, where 12 men were killed on January 2nd, 2006, and GFI was not ruled out as a possible cause (Gates et al. 2007). In New Zealand, the Pike River coal mine explosion disaster on November 19th 2010 killed 29 out of the total 31 underground workers at that time. As no one has been able to re-enter the coal mine after the explosion, the ignition source of the first explosion has not been determined by scene inspection and GFI remains a possible ignition source (Royal Commission on the Pike River Coal Mine Tragedy 2012). The mine geology, mining conditions and the incidents history at Pike River indi- cate a high possibility of frictional ignition in the goaf; It is a gassy mine, over a five-day period in October 2010 there were six over $5 \%$ methane overrun incidents, which mainly occurred in its hydro panel; sandstone, which has high incendivity, directly overlies the active coal seam with the thickness of over 30 meters; and the incendivity of the sandstone was substantiated by the frictional ignition incidents in the mine's tunnel development phase; it adopted free-standing goaf management strategy, and the coal extraction height was in 1013 meters range, which can yield friction velocity from 14 to $16 \mathrm{~m} / \mathrm{s}$, and this velocity range has been proven to be readily to cause frictional ignition; The width of the panel was 31 meters, which was capable to yield plate like rock falling, and this has been proven by the platelike roof falling with windblast on 30th October 2010, while the plate-like roof falling blocks can provide friction platform with sufficient sliding distance for the overlain falling rocks (Royal Commission on the Pike River Coal Mine Tragedy 2012).

The incidences of GFI have been reported even more in China. China extracts about half of the world's total coal production, and over $90 \%$ of that is from underground coal mines. On 14th February 1999, at Xinjian coal mine Qitaihe city of Heilongjiang Province, methane accumu- 
lated in an abandoned conveyor roadway which connected to a high gassy coal seam. The impact and friction associated with the cave-in of the rich quartz sandstone roof ignited the firedamp, and caused an explosion which killed 49 men (Yang \& Gu 2010); On 5th November 1999, at Yinan coal mine of Handan City in Hebei Province, methane built-up under the massive freestanding roof in the goaf, the friction and impact during the caving of the roof ignited the firedamp, caused an explosion which killed 33 men (Yang \& Gu 2010). At Meiyukou and Xinzhouyao coal mines of Datong Mining Group, goaf methane ignitions have been reported times, and the fires were called 'ghost fires' by underground coal miners. On 3rd December 2005, at 8317 fully mechanized longwall face in Xinzhouyao coal mine, during the goaf roof caving, a stream of flame came out of the goaf, which caused face stop for nearly 1 week. After analyzing and investigating the accident causes, open flame, blasting explosives and electrical charges were ruled out, and rock on rock frictional ignition was considered to be the most possible cause (Yang \& Gu 2010). A total of 26 goaf methane explosion (fire) incidents were reported in the counties of YangCheng and Qinshui in China. After ruling out the possibilities of open flame, blasting explosive, detonators, electrical arc and contrabands, these incidents were attributed to rock on rock frictional ignition (Qin 2005).

\section{MECHANISMS OF GFI}

The eventuation of frictional ignition relies on the copresence of both incendive ignition source and incendive environment. Systematic and comprehensive investigations were conducted on the ignition source, and the corresponding mechanisms were proposed, developed and substantiated by laboratory experiments and field observations. The study on incendivity of ignition environment mainly focused on the methane concentration of methane-air mixture. Some new factors which affect the incendivity of the environment have been identified by researchers and preliminarily probes have been conducted on these concerns. This section critically examines the ignition source mechanisms and their supporting laboratory tests, and distilled the core of research outcomes from the perspective of industrial engineering controls. This section also summarizes the new concerns on the incendivity of the environment and the ongoing research outcomes.

\subsection{Ignition source mechanisms}

From the perspective of ignition sources, frictional ignition can be broadly divided into three categories: rock on rock, metal on rock, metal on metal. As in the goaf area, the presence of metal is rare, so GFI can be classified as the rock on rock, which has been proven to be incendive enough to ignite explosive range methane-air admixture theoretically and experimentally. Insights into the corresponding mechanisms have gone through different phases and gradually matured (Burgess \& Wheeler 1928, Nagy \& Kawenski 1960, Page 2010, Rowell 1969, Powell \& Billinge 2001, Qin 2003, Qin 2005, Rae 1964, Ramsay et al. 1965, Ward et al. 2001, Wynn \& Britain 1952).

Although it was the sparks generated from the impacts and friction that raised the concern of frictional ignition, it has been proven that most of the frictional ignitions were not caused by sparks, provided that the sparking particles are not pyrite, which can burn in the air. Burgess and Wheeler from UK SMRE (Safety in Mines Research Establishment) found in the laboratory that it was very difficult to ignite admixtures of methane and air with sparks (Burgess \& Wheeler 1929), and Blickensderfer et al. from U.S. Bureau of Mines confirmed the above finding (Blickensderfer et al. 1972). Researchers revealed that methane ignition requires a high temperature (no less than $650^{\circ} \mathrm{C}$ ) associated with adequate heating area and induction time, while sparks do not usually possess the adequate combination of life time, temperature, and surface area (Trueman 1985). Australian researchers Ward et al. observed the ignitions associated with the presence of sparks, and found that ignitions mostly developed from the contact points of friction rather than sparks (Ward et al. 2001). Pyrite sparking particles are another story, because they can react with oxygen, generate more heat and keep the temperature going higher, and then prolong the lifetime above the incendive temperature (Ward et al. 2001, Allsop 1939). In conclusion, previous research conducted in laboratory illustrated that normal sparks which just hold the frictional heat are not capable of being the ignition source in most frictional ignition cases.

Hot spots consisting of molten minerals from sliding rocks, which appear at the contact point of sliding rocks and its trail, are the major contributor to frictional ignitions. Hot spots mechanism was firstly proposed in 1929, when Burgess and Wheeler argued that a stationary spark at the contact between cutting pick and the rock 
might be ignition source, which is equal to the hot spot (Burgess \& Wheeler 1929). Powell from UK SMRE reported that in a set of rubbing tests with rock sample cube rubbing against sandstone wheel enclosed in a 7\% methane-air mixture, when ignitions occurred, the subsequent examination always revealed patches of glassy, fused quartz on the rubbed surface of the rock sample cube, which were the chilled hot spots (Powell \& Billinge 1975). The high-speed cine-film, which recorded on another set of tests, also confirmed the presence of hot spots at the friction trace (Powell \& Billinge 1975, Powell et al. 1975). Ward et al. observed the frictional ignitions in his tests, and found that ignitions originated from the hot spots at the close trail of the contact point of friction (Ward et al. 2001). All the above laboratory findings underpin the hot spots mechanism, and theoretical interpretations were proposed as well.

Quantitative research was conducted, based on the appreciation of incendivity of rock on rock friction, aiming to provide data which engineering controls can be based upon and developed. Rae from UK SMRE conducted systematic research on the criteria of rock on rock frictional ignition by making use of highly incendive sandstone (Darley Dale sandstone) with the outcomes, as shown in Figure 1. (Rae 1964).

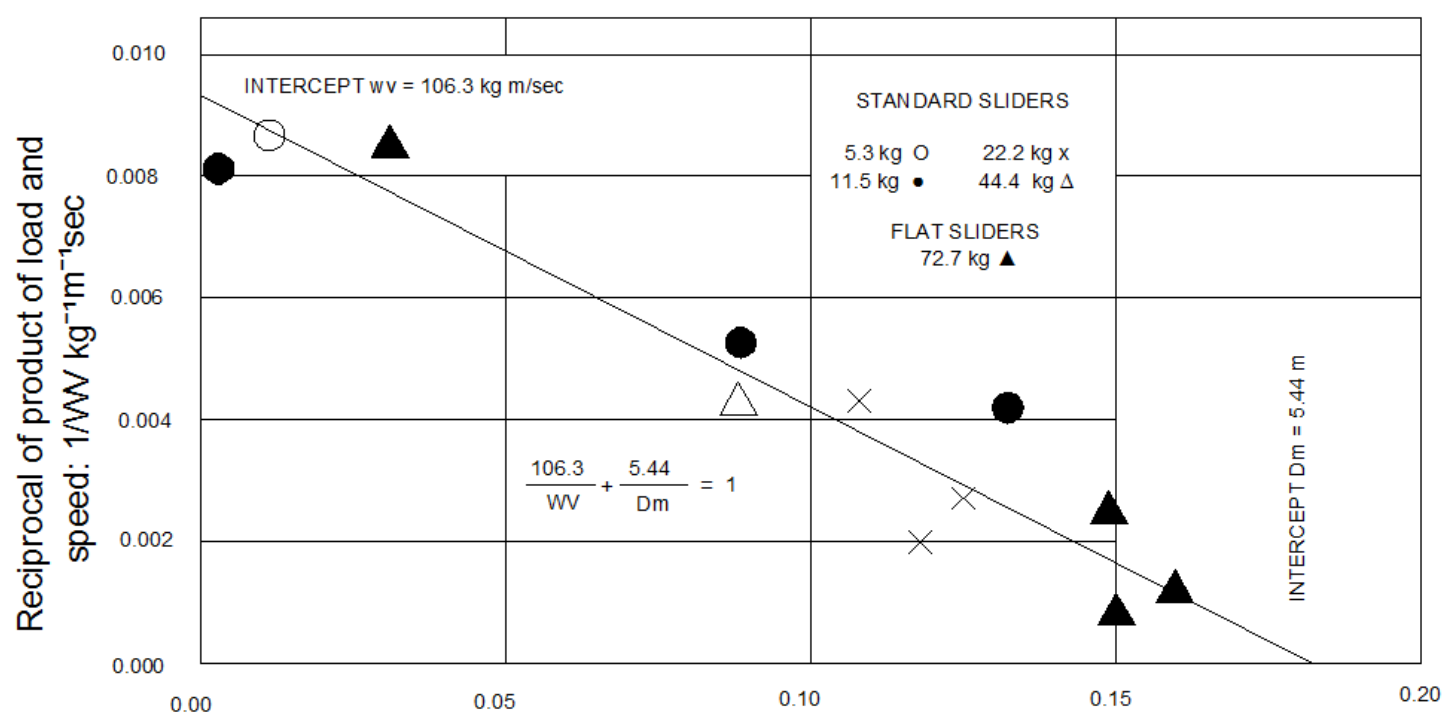

Reciprocal of mean distance to ignition: $1 / \mathrm{Dm} \mathrm{m}^{-1}$

Figure 1. Tests outcomes from UK SMRE (Rae 1964)

Figure 1 shows that the mean sliding distance prior to ignition is in inverse relationship with the momentum of the sliding, the larger the momentum the shorter the sliding distance is needed; while the most highlighted feature in Figure 1 is the existence of the threshold mean sliding distance prior to ignition, which in this spe- cific case is $5.44 \mathrm{~m}$ (1/0.1838). The existence of threshold friction distance prior to ignition is also demonstrated by the outcomes of the experiments conducted by Ward and $\mathrm{Xu}$, as shown in Table 1 and Table 2 respectively.

Table 1. Sliding time and distance prior to ignition for different rock sliders using sandstone wheel from Appin Colliery (Sample A1) (Ward et al. 2001)

\begin{tabular}{|c|c|c|c|c|c|}
\hline \multirow[t]{2}{*}{$\begin{array}{l}\text { Wheel speed } \\
\text { (rpm) }\end{array}$} & \multirow[t]{2}{*}{$\begin{array}{l}\text { Wheel speed } \\
(\mathrm{m} / \mathrm{s})\end{array}$} & \multicolumn{4}{|c|}{$\begin{array}{l}\text { Time to ignition for different rock samples used as sliders (s)/distance prior to ignition } \\
\text { (m) }\end{array}$} \\
\hline & & M1 Claystone & A1 Sandstone & FB1 Quartzite & SB10 Siliceous coal \\
\hline 700 & 5.1 & No ignition & $12 / 61.2$ & $2 / 10.2$ & $2 / 10.2$ \\
\hline 500 & 3.7 & No ignition & 28/103.6 & $15 / 55.5$ & $11 / 40.7$ \\
\hline 300 & 2.2 & No ignition & No ignition & $35 / 77$ & $30 / 66$ \\
\hline
\end{tabular}




\begin{tabular}{|c|c|c|c|c|c|c|}
\hline \multirow[t]{2}{*}{ Rock Type } & CH4 Concentration & $\begin{array}{l}\text { Contact Normal } \\
\text { Force }\end{array}$ & Sliding Speed & Sliding Time & \multirow[t]{2}{*}{ Number of Tests } & \multirow[t]{2}{*}{$\begin{array}{l}\text { Number of Explo- } \\
\text { sions }\end{array}$} \\
\hline & $\%$ & $\mathrm{~N}$ & $\mathrm{~m} \times \mathrm{s}^{-1}$ & $\mathrm{~s}$ & & \\
\hline Gritstone on Gritstone & $5 \sim 16$ & $120 \sim 150$ & 3 & $10 \sim 998$ & 10 & 0 \\
\hline $\begin{array}{l}\text { Conglomerate on Con- } \\
\text { glomerate }\end{array}$ & $5 \sim 16$ & $120 \sim 150$ & 3 & 10 998 & 10 & 0 \\
\hline $\begin{array}{l}\text { Mudstone on Conglomer- } \\
\text { ate }\end{array}$ & $5 \sim 16$ & $171 \sim 228$ & 10 & $9 \sim 60$ & 10 & 0 \\
\hline Mudstone on Gritstone & $5 \sim 16$ & $171 \sim 228$ & 10 & $9 \sim 60$ & 10 & 0 \\
\hline Gritstone on Gritstone & $5 \sim 16$ & $171 \sim 228$ & 10 & $6 \sim 32$ & 10 & 7 \\
\hline Conglomerate on Gritstone & $5 \sim 16$ & $171 \sim 228$ & 10 & $6 \sim 32$ & 10 & 8 \\
\hline $\begin{array}{l}\text { Conglomerate on Con- } \\
\text { glomerate }\end{array}$ & $5 \sim 16$ & $171 \sim 228$ & 10 & $2 \sim 32$ & 10 & 8 \\
\hline
\end{tabular}

Table 1 shows that, under Ward's experimental environment, the sliding distance prior to the frictional ignition decreases substantially with the increase of sliding speed and momentum; and even with the most incendive speed in the experiments, which was $5.1 \mathrm{~m} / \mathrm{s}$, the sliding distance prior to the frictional ignition was no less than $10.2 \mathrm{~m}$ (Ward et al. 2001). Table 2 shows that the dry conglomerate gave the highest incendivity; while even with the conglomerate against conglomerate under the contact pressure of $171-228 \mathrm{~N}$, the minimum sliding distance before frictional ignition was $20 \mathrm{~m}$ (which is worked out with $10 \mathrm{~m} / \mathrm{s} \times 2 \mathrm{~s}$ ) (Xu et al. 2007). The discrepancy of the minimum sliding distance prior to frictional ignition among the research outcomes of Rae, Ward and $\mathrm{Xu}$, was due to the different contact loads and rocks adopted in their experiments. The maximum contact loads adopted in Rae's experiments were much higher than those adopted by the other two researchers, and were more approximate to the realistic adverse underground environment. Nevertheless, all these research outcomes support that threshold sliding distances would be needed to yield incendive enough ignition sources.

The threshold sliding distance is backed by the heat requirement to yield incendive enough hot spots under the given experimental environment. According to the frictional heat accumulation theory, heat generated in the sliding process equals the normal stress load at the contact multiplies the dynamic friction coefficient and the sliding distance, as shown in Equation 1. The normal stress load at the contact cannot be infinite but limited by the rock strength and hardness, i.e. the force applied at the contact cannot exceed the strength of the sliding bodies; combining with the given heat requirement and the fixed range of dynamic friction coefficient in the defined environment, the minimum threshold sliding distance can be estimated with the following equation, in which the cooling procedure associated with the sliding is ignored.
$Q=F \times C \times L$

Where $Q=$ the heat generated in the friction process; $F=$ applied normal force at the contact; $\mathrm{C}=$ the dynamic frictional coefficient at the contact point; and $\mathrm{L}=$ sliding distance prior to the frictional ignition.

Besides the threshold sliding distance, the threshold sliding velocity is another decisive factor to yield incendive enough ignition sources. In the tests conducted by Rae from UK SMRE, the sliding speeds of $21.3 \mathrm{~m} / \mathrm{s}, 10.6 \mathrm{~m} / \mathrm{s}$, $5.3 \mathrm{~m} / \mathrm{s}, 5.3 \mathrm{~m} / \mathrm{s}$, and $1.6 \mathrm{~m} / \mathrm{s}$ were found to be the minimum speeds under the contact loads of $5.3 \mathrm{~kg}, 11.5 \mathrm{~kg}$, $22.2 \mathrm{~kg}, 44.4 \mathrm{~kg}$ and $72.7 \mathrm{~kg}$ respectively (Rae 1964). Ward's research also confirmed that the incendive rock on rock sliding under higher speed, which was $5.1 \mathrm{~m} / \mathrm{s}$, may lose its incendivity under lower speeds, which were $2.2 \mathrm{~m} / \mathrm{s}$ and $3.7 \mathrm{~m} / \mathrm{s}$ (Ward et al. 2001). Qin et al. conducted $\mathrm{Fl}$ tests under two sets of sliding speed, which were $4.2 \mathrm{~m} / \mathrm{s}$ and $7.43 \mathrm{~m} / \mathrm{s}$ with the same experimental environment, and found that $4.2 \mathrm{~m} / \mathrm{s}$ did not yield any frictional ignition while the speed of $7.43 \mathrm{~m} / \mathrm{s}$ yielded 13 frictional ignitions out of the 29 experiments (Qin et al. 2005). In the tests conducted by Xu et al., the $3 \mathrm{~m} / \mathrm{s}$ sliding speed did not yield frictional ignitions while $10 \mathrm{~m} / \mathrm{s}$ sliding speed yielded frictional ignitions, as shown in Table 2. (Xu et al. 2007).

Cooling process associated with the frictional heating up is the underlying rational of the threshold sliding speed requirement. Blickensderfer conducted research on the cooling process of the trail of the sliding; and a cooling model was proposed and validated based on the research outcomes of the laboratory experiments; a typical cooling curve of the sliding trail based on the theory is shown in Figure 2 (Blickensderfer 1975). The theoretical model revealed that the lifetime of hot streaks on the trail of the contact point over the minimum ignition temperature of methane-air admixture stays within very short time, which is less than 10 milliseconds; combining 
with the finding that a threshold area of hot spot is needed to ignite methane-air mixture under the given temperature (Powell 1969, Rae et al. 1964), and sliding width is fixed under a specific friction, then the area of the hot streaks with temperature over the minimum ignition temperature is in direct proportion with the sliding speed (Blickensderfer 1975). So, a threshold sliding speed is needed to reach or overtake the threshold hot spot area to yield an incendive ignition source.

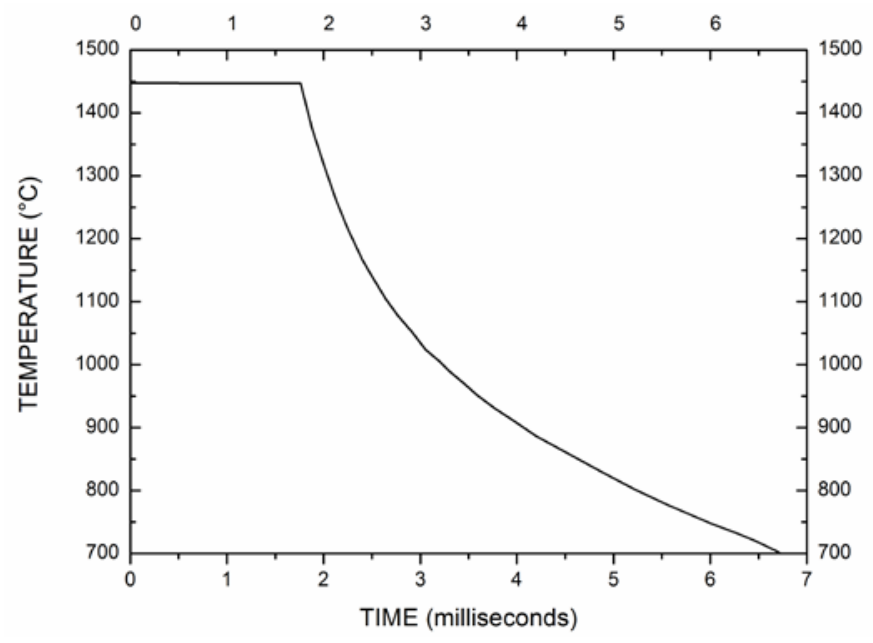

Figure 2. Calculated cooling curve of a narrow zone in the hotstreak trail (Blickensderfer 1975)

In conclusion, apart from the frictional ignitions originating from pyrite sparks, which can burn in the air; in given environment, the eventuation of frictional ignition relies on the presence of hot spots with enough incendivity. The presence of the incendive frictional ignition sources requires minimum threshold friction distance and friction speed.

\subsection{Ignition environment mechanisms}

From the perspective of ignition environment, even though it has been well established that the ignitable range of methane concentration is from $5 \%$ to $15 \%$, the ignitable oxygen concentration is no less than $12 \%$, and the methane concentration of $7 \%$ has the highest incendivity (Ramsay et al. 1965, Rae et al. 1964, Cutler 1974); new concerns in this regard have arisen from the industry. One notable concern is the presence of liquid hydrocarbon; an underground coal mine in Utah, USA came across some liquid hydrocarbon in the coal measures strata, and U.S. NIOSH (National Institute for Occupational Safety and Health) laboratory experiments have confirmed that with the presence of the liquid hydrocarbon, the frictional ignitions are much easier to be trig- gered (Cashdollar 2008). Not only in USA, but some mines around other parts of the world are facing the presence of liquid hydrocarbons. Armstrong reported that oil occurrence has been observed in the three strata overlying the major active Bulli coal seam, among which, coal cliff sandstone directly overlaid on the coal seam, while Scarborough sandstone and Bulgo sandstone are the third and fifth overlying strata respectively (Armstrong et al. 2006). Although it has not been recorded in accessible literature, the presence of liquid carbon hydrogen in underground coal mines is not rare in China as well.

The incendivity of the environment can also be boosted by the increase of virgin rock temperature (VRT). Theoretically, it has been supported by the frictional ignition predicting model developed by Blickensderfer, in which higher temperatures of the sliding bodies boost the frictional heating up and ease cooling speed as well as intensity of the trail (Blickensderfer 1975). The studies conducted by China Coal Research Institute show that the increasing of environmental temperature will significantly boost the incendivity of the rock friction (Qin et al. 2005); Qin et al. conducted rock on rock frictional ignition experiments under different environment temperatures (which were also the initial rock temperature) with the same other parameters, and found that clusters of sparks were seen with temperature reaching $10^{\circ} \mathrm{C}$ while no sparks were seen under $5{ }^{\circ} \mathrm{C}$ (Qin et al. 2005). Even though the model developed by Blickensderfer included the temperature as a variable, no verifying experiments have been done by taking it as the independent variable, which can be done in further study.

Another concern on frictional ignition environment is the presence of higher incendive gas content in the methane-air admixture at some local areas, especially in the areas of oxidation and temperature rising zone in the goaf, where thermal decomposition gas product of coal volatile can be expected. The presence of these contents would increase the incendivity of the local gas environment (Li et al. 2012). This concern is backed by the research outcomes of methane, oxygen, and spontaneous combustion danger area distribution pattern in the goaf area. Chinese researchers conducted methane and oxygen concentration monitoring in the goaf area of $U$ shape ventilation Longwall panel, and obtained methane distribution in the goaf area as shown in Figure 3 (Yang \& Gu 2010). 


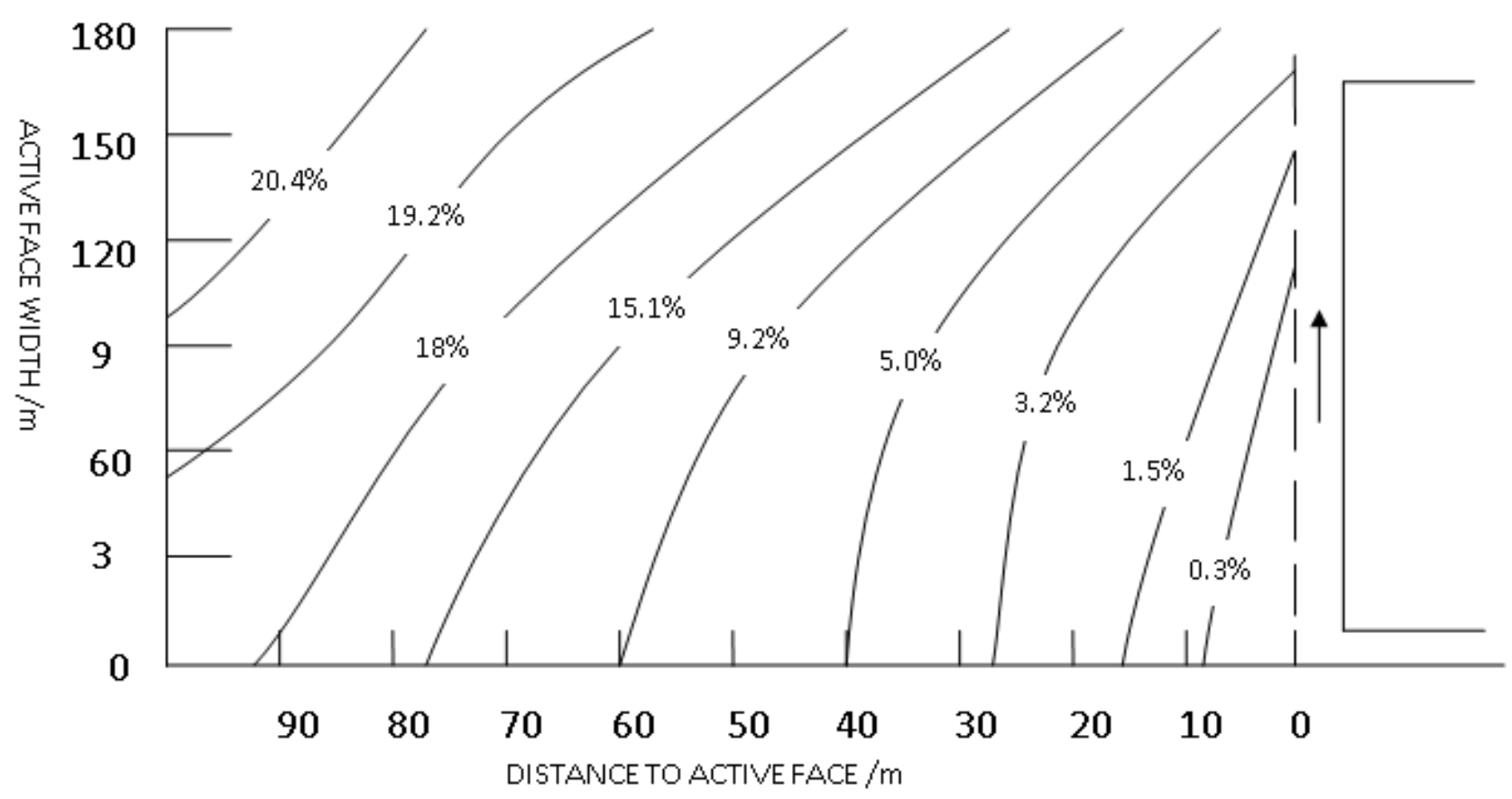

Figure 3. Methane distribution pattern in the goaf of a Longwall panel in China (Yang \& Gu 2010)

Figure 3 shows that the explosive range of methane exists between 10 to 76 meters inby the goaf. Combining with previous research outcomes of the oxygen distribution pattern in the goaf under the spontaneous combustion research, which is that the heat elimination through ventilation zone is between 0 and 25 meters with oxygen concentration of 20 to 16 per cent, the oxidation and temperature raising zone is between 25 and 60 meters with oxygen concentration of 16 to 7 per cent, and asphyxiation zone with oxygen concentration of less than 7 per cent; it is highly probable that there are overlapping areas with explosive mixture of oxygen, methane and presence of gas products from thermal decomposition of coal volatile. It would be meaningful to further investigate the gas make of the product of thermal decomposition of coal volatile and its enhancing effect of the incendivity of the methane-air admixture gas body.

In summary, the presence of incendive ignition source relies on presence of threshold sliding distance and sliding speed for the incendive rocks; the incendivity of the environment can be boosted by the presence of liquid carbon hydrogen, the increase of virgin rock temperature, and the presence of the gas product of the thermal decomposition product of coal volatile. Although the mechanisms of ignition source have been systematically studied, the new concerns regarding the incendivity of the environment have just been preliminarily probed.

\section{GFI CONTROLS}

GFI controls are divided into two categories: frictional ignition source controls and frictional ignition environment controls. The rational underlying ignition source controls is to avoid the presence of the threshold values of the friction momentum, speed and distance. Frictional ignition environment controls rely on avoidance of the presence of methane-air mixture in explosive range and the presence of the higher incendive thermal decomposition gas product of coal volatiles in the areas where incendive ignition sources are likely present.

\subsection{GFI source controls}

Forced or induced roof caving, goaf backfilling and partial extraction can all limit the possible friction speed between the rocks by controlling the free-standing height of the overhang roof, according to the terminal speed of free falling theory.

$\mathrm{V}=\sqrt{2 \mathrm{gh}}=4.43 \sqrt{\mathrm{h}}$

Where $V=$ the terminal speed of falling rocks; $h=$ the free-standing height of the overhang roof. Among these three control measures, forced roof caving is the most economical and practical one and has been adopted widely to tackle this issue (Yang \& Gu 2010, Qin et al. 2003). Goaf backfilling and partial extraction have been adopted in some underground coal mines for surface 
subsidence control or resource recovery reasons, and are helpful for GFI control. The required forced caving height can be worked out with the following formula:

$\mathrm{h}_{\mathrm{e}}-\mathrm{h}_{\mathrm{f}}(\mathrm{k}-1)=\mathrm{H}_{\text {threshold }}$

Where $h_{e}=$ coal extracting height; $h_{f}=$ forced caving height; $\mathrm{k}$ = swell factor of the forced caving rocks;

$H_{\text {threshold }}=$ the threshold free-standing height which can yield the threshold terminal speed.

Forced roof caving can avoid the presence of massive friction contact load by avoiding the weighting associated with the falling of massive volume of free standing roof. The presence of large areas (even up to hundreds of thousands of square meters) of free standing overhang hard conglomerate or sandstone roof has been reported in underground coal mines. The fall of such large area of rock would incur massive load at the contact point of friction, which would be very highly incendive. Forced roof caving with designed increment value will keep the falling rock mass within the designated range, which will significantly alleviate the load at the friction contact.

Forced roof caving can also avoid the presence of incendive sliding distance. By implementing forced roof caving with reasonable increment, the formation of rock blocks with large surface, especially plate-like falling of roof strata, which can provide incendive sliding distance, is avoided. In conclusion, the forced or induced roof caving can limit the possible friction speed between the rocks, limit friction load at the contact, and avoid the presence of rock surface which can provide long enough sliding distance.

\subsection{GFI environment controls}

Keeping the methane concentration beyond the explosive range is the most effective and preferable approach on this issue. To control the methane level below the explosive fringe under a particular panel ventilation system is mainly achieved by removing methane emissions from the goaf. Bleeder system has been widely adopted by the industry to achieve this; the bleeder system can take away the methane emission from the goaf or adjacent methane bearing strata, as shown in Figure 4 .

Figure 4 shows the use of a bleeder system. The on-site monitoring results showed that the outcome was very satisfactory; the methane concentration of the general gas body was kept below $3 \%$ after the coal face had passed over 80 meters (Qin et al. 2003). However the bleeder system should not be adopted in coal faces with a high risk of spontaneous combustion.

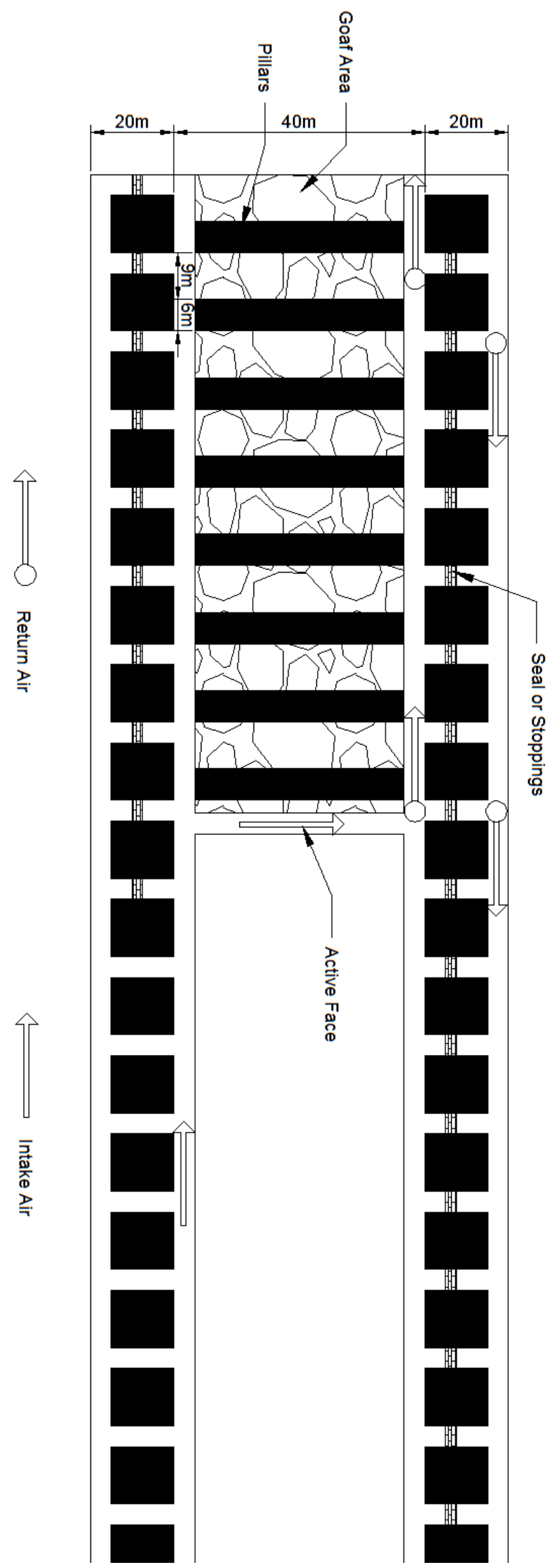


Figure 4. The use of a bleeder system to keep the methane concentration below the explosive range at a room and pillar panel (Qin et al. 2003)

Rapid goaf sealing technology is another practical approach to keep methane concentration beyond the explosive range. If the goaf can be sealed tightly within short time, methane emission from the goaf can be isolated, which would promptly raise the methane concentration in the goaf and simultaneously reduce the oxygen concentration to below the lean flammability limit; thereby the risk of frictional ignition can be eliminated (Qin et al. 2003). In June 2001, an industrial trial was conducted in an underground coal mine in China with a rapid goaf sealing method; the goaf was sealed with around 30 minutes. After the sealing, tube bundle was used to monitor the gas content on the goaf side of the seal, and the results are shown as in Figure 5 (Qin et al. 2003).

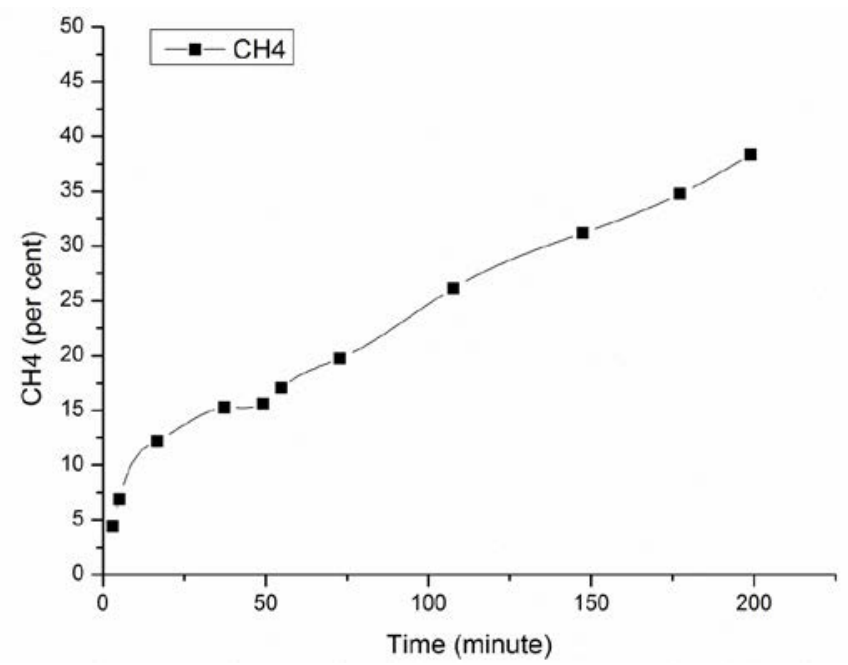

Figure 5. Methane concentration variation after rapid goaf sealing (Qin et al. 2003)

Figure 5 shows that within around an hour after goaf sealed off, the methane concentration of the general gas body on the goaf side of the seal passed the explosive range. The rapid goaf sealing technology is not universally adoptable; it cannot be applicable in active Longwall panel but is very effective in room and pillar or hydro mining panel as shown in Figure 4, especially after a large scale plate-like roof fall, which might create a very favorable condition for the incendive rock on rock friction.

\section{CONCLUSION}

GFIs in underground coal mines pose a serious safety threat that may potentially lead to major gas explosions or fires. This paper provided an examination of GFI incidents and their underlying mechanisms. The eventuation of frictional ignition incidents relies on co-presence of both incendive ignition source and incendive environment. The presence of incendive ignition source depends on two critical and decisive parameters, i.e. the friction distance and friction speed. The incendivity of the environment is generally determined by the methane, oxygen concentrations, and can be boosted by the presence of liquid hydrocarbon, the increase of virgin rock temperature, and the presence of hydrocarbon gases from thermal decomposition product of coal volatile. Effective control measures can be developed to limit the friction distance and friction speed associated with rock falls in the goaf, therefore avoid the development of an incendive ignition source; they can also be developed by keeping the methane-air admixture beyond the explosive range. These control measures include forced or induced roof caving, bleeder ventilation system and rapid goaf seal-off.

\section{ACKNOWLEDGEMENTS}

This work is sponsored by a scholarship from the University of Wollongong and the China Scholarship Council.

\section{REFERENCES}

Allsop, G. \& Wheeler, R.V. 1939. The ignition of firedamp by pyrites during coal cutting. Transactions of the Institution of Mining Engineers 1938-39, XCVI.

Armstrong, M. et al. 2006. Determining the controls for strata gas and oil distribution within sandstone reservoirs overlying the bulli seam. Proceedings of Coal Operators' Conference, University of Wollongong, Wollongong, NSW, Australia.

Blickensderfer, R. 1975. Methane Ignition by Frictional Impact Heating. Combustion and Flame, 25: p. 10.

Blickensderfer, R. et al. 1972. Testing of coal cutter materials for incendivity and radiance of sparks. U.S. Bureau of Mines, Report RI 7713.

Burgess, M.J. \& Wheeler, R.V. 1928. The ignition of firedamp by the heat of impact of rocks. [Gt. Brit.] Mines department, Safety in mines research board.

Burgess, M.J. \& Wheeler, R.V. 1929. The Ignition of Firedamp by the Heat of Impact of Metal Against Rock. UK Safety in Mines Research Board: Sheffield. 
Cashdollar, K.L. 2008. Frictional Ignition of Methane-Air in the Presence of Liquid Hydrocarbons. Department of health and human services, National Institute for Occupational Safety and Health, DHHS (NIOSH) Publication No. 2008-124.

Cutler, D.P. 1974. The ignition of gases by rapidly heated surfaces. Combustion Flame, 22: p. 105-109.

Gates, R.A. et al. 2007. Report of investigation, fatal underground coal mine explosion, January 2, 2006, Sago Mine, Wolf Run Mining Company, Tallmansville, Upshur County, West Virginia, ID No. 46-08791. United States department of labor, Mine safety and health administration, Coal mine safety and health.

Li, G. et al. 2012. Influence of coal particles on methane/air mixture ignition in a heated environment. Journal of Loss Prevention in the Process Industries, 1(5).

Lynn, K.P. et al. 1986. Report on an accident at Moura No.4 underground mine, Warden's Inquiry. Department of natural resources and mines, Queensland Government.

Nagy, J. \& Kawenski, E.M. 1960. Frictional ignition of gas during a roof fall. U.S. Bureau of Mines. Report of investigations 5548, Washington.

Page, N.G. et al. 2010. Report of investigation, fatal underground mine explosion, April 5, 2010, Upper Big Branch Mine-South, Performance Coal Company, Montcoal, Raleigh County, West Virginia, ID No. 46-08436. United States department of labor, Mine safety and health administration, Coal mine safety and health.

Powell, F. 1969. Ignition of gases and vapors - Review of ignition of flammable gases and vapors by friction and impact. Industrial \& Engineering Chemistry, 61(12): p. 9.

Powell, F. \& Billinge, K. 1975. The frictional ignition hazard associated with colliery rock. The Mining Engineer, 134: p. 8.

Powell, F. et al. 1975. The ignition of methane-air by machine picks cutting into rock. 16th International Conference on Coal Mine Safety Research, Washington D.C. .

Qin, Y.J. et al. 2003. Comprehensive prevention and control technologies on goaf gas explosions (fires). Safety In Coal Mines, 34(2). Journal ISSN:1003-496X. Paper Accession Number:1003-496X(2003)11-0006-02.

Qin, Y.J. et al. 2005. The determination of ignition sources of goaf gas explosions (fires). Safety In Coal Mines, 36(7). Journal ISSN:1003-496X. Paper Accession Number:1003496X(2005)07-0035-03.

Rae, D. 1964. The role of quartz in the ignition of methane by the friction of rocks. Safety in Mines Research Establishment, Research report No.223, Minstry of Power.

Rae, D. et al. 1964. The size and temperature of a hot square in a cold plane surface necessary for the ignition of methane. Safety in Mines Research Establishment, Research report No.224, Minstry of Power.

Ramsay, H.T. et al. 1965. A summary account of the manner and the frequency of ignition of firedamp in British Coal Mines. The Mining Engineer, Vol.124.
Royal Commission on the Pike River Coal Mine Tragedy Report. 2012. Royal Commission on the Pike River Coal Mine Tragedy. Wellington, New Zealand.

Trueman, R. 1985. A literature review of the ignition of methane-air mixtures by coal-cutting picks. Journal of the South African Institute of Mining and Metallurgy, 85(7): p. 7.

Ward, C.R. et al. 2001. Identification of potential for methane ignition by rock friction in Australian coal mines. International Journal of coal geology, 45: p. 13.

Wynn, A.H.A. \& Britain, G. 1952. The ignition of firedamp by friction. UK Safety in Mines Research Establishment, Ministry of Fuel and Power, Research report 42.

Xu, J.L. et al. 2007. Study on Gas Explosion Induced by Impact-Friction Sparks During Roof Collapse with FullyMechanized Top-Coal Caving Mining. Journal of China University of Mining \& Technology, 36(1). Paper Accession Number:1000-1964(2007)01-0012-05.

Yang, T.B. \& Gu, J.J. 2010. Prelinary probe into goaf area rock on rock frictional ignition and the induced gas explosion. Safety In Coal Mines, Journal ISSN:1003-496X. Paper Accession Number:1003-496X(2010)08-0111-03. 